\title{
Effect of GnRH Analogs Leuprolide-Acetate and Triptorelin on Bone Mineral Density in Girls with Central Precocious Puberty
}

\author{
Siegfried Bauer, M.D., Hyo-Kyoung Nam, M.D., Young Jun Rhie, M.D., \\ Sang Hee Park, M.D. and Kee-Hyoung Lee, M.D. \\ Department of Pediatrics, Korea University College of Medicine, Seoul, Korea
}

\begin{abstract}
Purpose: The objective of this study was to evaluate the effect of gonadotropin releasing hormone analog $(\mathrm{GnRHa})$ treatment on bone mineral density (BMD) in girls with central precocious puberty (CPP). Further we investigated the differences in the effect on BMD by using the GnRHa leuprolide-acetate and triptorelin.

Methods: Sixty-one females with CPP were enrolled in the study, the lumbar spine BMD was measured by dual energy x-ray absorptiometry before treatment, after one year $(n=61)$ and after two years $(n=24)$ of treatment. Lumbar spine BMD standard deviation scores (SDS) were compared according to chronological age (CA) and bone age (BA) for the whole group, as well as for the group $A$, treated with leuprolide-acetate $(n=40)$, and the group $B$, treated with triptorelin $(n=21)$.

Results: All subjects showed significant increment in BMD during treatment $(P<0.05)$. Lumbar spine BMD SDS for $\mathrm{CA}$ and BA showed no significant changes before and during treatment. Group A and group B, within each group, showed no significant changes in lumbar spine BMD SDS for CA and BA during treatment.

Conclusion: Our study suggests that lumbar spine BMD was not impaired in girls treated with GnRHa for CPP and both leuprolide-acetate and triptorelin showed comparable effects on lumbar spine BMD during treatment. (J Korean Soc Pediatr Endocrinol 2011;16:106-111)
\end{abstract}

Key Words: Puberty, precocious; Bone density; Gonadotropin releasing hormone agonist; Leuprolide; Triptorelin

Introduction

Central precocious puberty (CPP) is usually defined as the beginning of secondary sexual characteristics before the age of 8 years in girls and 9 years in boys ${ }^{1)}$. It leads to an early development of secondary sexual characteristics, increase in growth velocity, resulting in decreased final adult height due to early fusion of epiphyseal growth plates²).

Synthetic gonadotropin releasing hormone analogs (GnRHa) have been introduced in the early 1980s to suppress the gonadotropin secretion in treatment of CPP. Long-acting GnRHa downregulate the receptors of the pituitary gland, leading to a desensitization of pituitary gonadotropin secre- tion $^{3)}$. As a result sex hormone release is suppressed, preventing an early fusion of the growth plates.

There has been concerned about the side effects of longterm GnRHa therapy in children, leading to a reduction in bone mineral density (BMD). The recovery of the hypothalamus-pituitary-gonad axis after therapy with continuity of normal menstruation has been demonstrated ${ }^{4,5)}$. However, the effects on BMD are controversial ${ }^{6-9)}$.

Our study aimed to evaluate the efficacy of long-term GnRHa therapy and possible side effects on bone mineralization in Korean girls with CPP. Further we compared the effect of therapy on lumbar spine BMD results with GnRHa leuprolide-acetate and triptorelin.

Received: 22 July, 2011, Revised: 19 July, 2011

Accepted: 24 July, 2011

Address for correspondence: Kee-Hyoung Lee, M.D.

Department of Pediatrics, Korea University College of Medicine,

Anam-dong 5-ga, Seongbuk-gu, Seoul 136-705, Korea

Tel: +82.2-920-6604, Fax: +82.2-922-7476

E-mail: khlee218@kumc.or.kr

106 대한소아내분비학회지 : 제 16 권 제 2호 2011년 


\section{Materials and Methods}

\section{Subjects}

In this retrospective study we reviewed the records of 61 Korean girls with CPP, from January 2007 to September 2010 at pediatric endocrinology clinic at Korea University Hospital. All subjects received treatment with GnRHa leuprolide-acetate or triptorelin for more than 1 year.

Diagnosis of CPP was based on the premature appearance of pubertal signs before the age of 8 years (breast development Tanner stage 2 or more), bone age (BA) more than 1 year beyond chronological age (CA) and a peak serum leuteinizing hormone $(\mathrm{LH})$ response $\geq 5.0 \mathrm{mlU} / \mathrm{mL}$ on the GnRH stimulation test. Pubertal development was determined according to Tanner method. Secondary causes for precocious puberty had been excluded from the study.

\section{Methods}

Among 61 patients, 40 received treatment with GnRHa leuprolide-acetate at a dose of $100 \mu \mathrm{g} / \mathrm{kg}$ (Lucrin depot ${ }^{\circledR}$, Abbott, Seoul, Korea), assigned to group A, whereas 21 patients received treatment with triptorelin at a dose of $100 \mu \mathrm{g} / \mathrm{kg}$ (De capeptyl depot ${ }^{\circledR}$, Ferring, Seoul, Korea), forming group B. Both substances were given by subcutaneous injection, every 28 days.

Among all 61 patients, 24 patients had a follow up period over 2 years. Height, weight, pubertal stage, BA, thyroid function test, insulin-like growth factor-1 (IGF-1), insulin-like growth factor binding protein-3 (IGFBP-3) were evaluated before beginning the treatment. Patient's height, weight and pubertal signs were evaluated every 3 months. They underwent BA study every 6 months. BA was assessed using an $\mathrm{x}$ ray of the left hand, according to the Greulich and Pyle method $^{10)}$. Predicted adult height $(\mathrm{PAH})$ was calculated according to the method of Bayley and Pinneau ${ }^{11)}$. Lumbar spine BMD at baseline and after each year was measured by dual energy x-ray absorptiometry (DEXA; Discovery A, Hologic, Bedford, MA, USA). BMD (measured in $\mathrm{g} / \mathrm{cm}^{2}$ ) was calculated from first to fourth lumbar vertebrae. Lumbar spine BMD results were compared with age- and sex-matched reference values ${ }^{12)}$, data which are used by the DEXA- manufacturer as normal reference values, and standard deviation score (SDS) for CA and BA was calculated accordingly.

\section{Statistical analyses}

Results are expressed as mean \pm SD. Statistical analyses were performed using paired t test and Wilcoxon signed-rank test. All statistical analyses were performed using the SPSS for Windows (version 12.0, SPSS Inc., Chicago, IL, USA). A $P$ value of less than 0.05 was considered statistically significant.

\section{Results}

\section{Clinical characteristics of all subjects with CPP}

61 girls treated for CPP with GnRHa were enrolled in the study. All had a follow up period over 1 year, whereas 24 girls had a follow up period over 2 years. The subjects were divided into 2 groups: group A $(n=40)$ treated with leuprolide-acetate, and group B $(\mathrm{n}=21)$ treated with triptorelin.

The baseline characteristics of all 61 girls are shown in Table 1. CA at initiation of therapy was $8.5 \pm 0.6$ years, and BA was $10.1 \pm 0.7$ years. Height increased during 2 years of treatment from initial $135.4 \pm 4.7 \mathrm{~cm}$ to $145.3 \pm 4.3 \mathrm{~cm}$. Target height of total group was $160.6 \pm 3.5 \mathrm{~cm}$. PAH at start of therapy was $155.4 \pm 5.2 \mathrm{~cm}$, and increased to $161.3 \pm 5.0$ $\mathrm{cm}$ after 2 years of treatment. The changes of clinical para-

Table 1. Clinical parameters of 61 girls with central precocious puberty at start of treatment, after 1 year and after 2 years of treatment

\begin{tabular}{lccc}
\hline & $\begin{array}{c}\text { Baseline } \\
(\mathrm{n}=61)\end{array}$ & $\begin{array}{c}\text { After 1 yr } \\
(\mathrm{n}=61)\end{array}$ & $\begin{array}{c}\text { After 2 } \mathrm{yr} \\
(\mathrm{n}=24)\end{array}$ \\
\hline CA (yr) & $8.5 \pm 0.6$ & $9.5 \pm 0.6$ & $10.5 \pm 0.6$ \\
BA (yr) & $10.1 \pm 0.7$ & $10.7 \pm 0.7$ & $11.2 \pm 0.6$ \\
BA/CA & $1.18 \pm 0.19$ & $1.12 \pm 0.10$ & $1.06 \pm 0.06$ \\
Height (cm) & $135.4 \pm 4.7$ & $141.3 \pm 4.6$ & $145.3 \pm 4.3$ \\
Height SDS & $1.28 \pm 0.75$ & $1.23 \pm 0.74$ & $1.01 \pm 0.68$ \\
Weight (kg) & $33.8 \pm 4.9$ & $38.8 \pm 6.3$ & $41.1 \pm 6.2$ \\
BMI (kg/m $\left.{ }^{2}\right)$ & $18.4 \pm 2.0$ & $18.7 \pm 2.3$ & $19.3 \pm 2.4$ \\
PAH $(\mathrm{cm})$ & $155.4 \pm 5.2$ & $160.1 \pm 5.4$ & $161.3 \pm 5.0$ \\
TAH $(\mathrm{cm})$ & $160.6 \pm 3.5$ & &
\end{tabular}

Values are presented as mean $\pm \mathrm{SD}$.

Comparing the baseline data with after 1 year and after 2 years, all data showed statistically significance $(P<0.05)$. Abbreviations: CA, chronological age; BA, bone age; SDS, standard deviation score; BMI, body mass index; $\mathrm{PAH}$, predicted adult height; TAH, target adult height. 
meters over 2 years of treatment were statistically meaningful $(P<0.05)$.

\section{Comparison of clinical characteristics between group A (treated with leuprolide-acetate) and group $B$ (treated with triptorelin)}

The baseline clinical characteristics of the two groups, group A $(n=40)$ and group B $(n=21)$ are compared in Table 2 . Both groups showed no difference in drug dosage with a mean dose of $0.10 \pm 0.01 \mathrm{mg} / \mathrm{kg}$. Group A showed an earlier onset of therapy in age with a mean CA of $8.3 \pm 0.6$ years, and mean BA of $9.7 \pm 0.6$ years, compared to group B, with a CA of $9.0 \pm 0.6$ years, and BA of $10.6 \pm 0.5$ years $(P<0.05)$. However, there was no difference in the ratio of $\mathrm{BA} / \mathrm{CA}$ between the two groups. PAH of both groups was also not significantly different.

Table 2. Baseline clinical parameters of group A (leuprolideacetate) and group B (triptorelin)

\begin{tabular}{lccl}
\hline & $\begin{array}{c}\text { Group A } \\
\text { (leuprolide) }\end{array}$ & $\begin{array}{c}\text { Group B } \\
\text { (triptorelin) }\end{array}$ & $P$ value \\
\hline Drug dose (mg/kg) & $0.10 \pm 0.01$ & $0.10 \pm 0.01$ & 0.06 \\
CA (yr) & $8.3 \pm 0.6$ & $9.0 \pm 0.6$ & 0.001 \\
BA (yr) & $9.7 \pm 0.6$ & $10.6 \pm 0.5$ & 0.001 \\
BA/CA ratio & $1.16 \pm 0.15$ & $1.17 \pm 0.17$ & 0.06 \\
Height (cm) & $133.2 \pm 3.5$ & $139.5 \pm 3.8$ & 0.001 \\
Height SDS & $1.19 \pm 0.7$ & $1.47 \pm 0.8$ & 0.2 \\
TAH (cm) & $155.5 \pm 4.1$ & $155.7 \pm 2.1$ & 0.87 \\
PAH (cm) & $159.2 \pm 5.2$ & $159.6 \pm 5.5$ & 0.26 \\
\hline
\end{tabular}

Values are presented as mean $\pm \mathrm{SD}$.

Abbreviations: CA, chronological age; BA, bone age; SDS, standard deviation score; TAH, target adult height; $\mathrm{PAH}$, predicted adult height.

\section{The changes of lumbar spine BMD during GnRHa treatment}

Lumbar spine BMD values of the subjects steadily increased during treatment significantly, from initial $0.61 \pm 0.06$ to $0.65 \pm 0.06 \mathrm{~g} / \mathrm{cm}^{2}$ after 1 year, and to $0.67 \pm 0.05 \mathrm{~g} / \mathrm{cm}^{2}$ after 2 years of treatment. The lumbar spine BMD SDS for CA and BA did not change significantly during therapy (Table 3 ).

Table 4 shows the changes of lumbar spine BMD values of group A (leuprolide-acetate) and group B (triptorelin) during 2 years of treatment. In group A lumbar spine BMD values steadily increased during treatment with significance, from initial $0.60 \pm 0.06$ to $0.66 \pm 0.06 \mathrm{~g} / \mathrm{cm}^{2}$ after 2 years of treatment $(P<0.05)$. In group B lumbar spine BMD also steadily increased during treatment, from initial $0.64 \pm 0.05$ to $0.69 \pm 0.04 \mathrm{~g} / \mathrm{cm}^{2}$ after 2 years of treatment $(P<0.05$, Fig. 1$)$. Lumbar spine BMD SDS for CA (Fig. 2) and BA (Fig. 3) did

Table 3. The changes of the bone mineral density of the lumbar spines during treatment

\begin{tabular}{cccc}
\hline & $\begin{array}{c}\text { Baseline } \\
(\mathrm{n}=61)\end{array}$ & $\begin{array}{c}\text { After 1 yr } \\
(\mathrm{n}=61)\end{array}$ & $\begin{array}{c}\text { After 2 } \mathrm{yr} \\
(\mathrm{n}=24)\end{array}$ \\
\hline $\begin{array}{c}\text { Lumbar spine } \\
\text { BMD }\left(\mathrm{g} / \mathrm{cm}^{2}\right)\end{array}$ & $0.61 \pm 0.06$ & $0.65 \pm 0.06^{*}$ & $0.67 \pm 0.05^{*}++$ \\
$\begin{array}{c}\text { Lumbar spine } \\
\text { BMD SDS CA }\end{array}$ & $0.70 \pm 0.86$ & $0.68 \pm 0.80$ & $0.65 \pm 0.57$ \\
$\begin{array}{c}\text { Lumbar spine } \\
\text { BMD SDS BA }\end{array}$ & $-0.08 \pm 0.73$ & $-0.03 \pm 0.71$ & $-0.15 \pm 0.56$ \\
\hline
\end{tabular}

Values are presented as mean $\pm \mathrm{SD}$.

Abbreviations: BMD, bone mineral density; CA, chronological age; BA, bone age; SDS, standard deviation score.

${ }^{*} P<0.05$ compared with baseline

${ }^{\dagger} P<0.05$ compared with year 1 .

Table 4. The bone mineral density of the lumbar spines in group A (leuprolide-acetate) and group B (triptorelin) during treatment

\begin{tabular}{|c|c|c|c|}
\hline & Baseline & After $1 \mathrm{yr}$ & After $2 \mathrm{yr}$ \\
\hline Group A (leuprolide) & $(n=40)$ & $(n=40)$ & $(n=14)$ \\
\hline Lumbar spine BMD & $0.60 \pm 0.06$ & $0.63 \pm 0.06^{*}$ & $0.66 \pm 0.06^{*},+$ \\
\hline Lumbar spine BMD SDS CA & $0.67 \pm 0.94$ & $0.64 \pm 0.87$ & $0.50 \pm 0.64$ \\
\hline Lumbar spine BMD SDS BA & $-0.06 \pm 0.79$ & $0.00 \pm 0.78$ & $-0.21 \pm 0.70$ \\
\hline Group B (triptorelin) & $(n=21)$ & $(n=21)$ & $(n=10)$ \\
\hline Lumbar spine BMD & $0.64 \pm 0.05$ & $0.67 \pm 0.05^{\star}$ & $0.69 \pm 0.04^{*}$ \\
\hline Lumbar spine BMD SDS CA & $0.76 \pm 0.69$ & $0.74 \pm 0.64$ & $0.70 \pm 0.55$ \\
\hline Lumbar spine BMD SDS BA & $-0.12 \pm 0.62$ & $-0.09 \pm 0.56$ & $-0.06 \pm 0.29$ \\
\hline
\end{tabular}

Values are presented as mean $\pm \mathrm{SD}$.

Abbreviations: BMD, bone mineral density; CA, chronological age; BA, bone age; SDS, standard deviation score.

${ }^{*} P<0.05$ compared with baseline.

${ }^{\dagger} P<0.05$ compared with year 1 . 


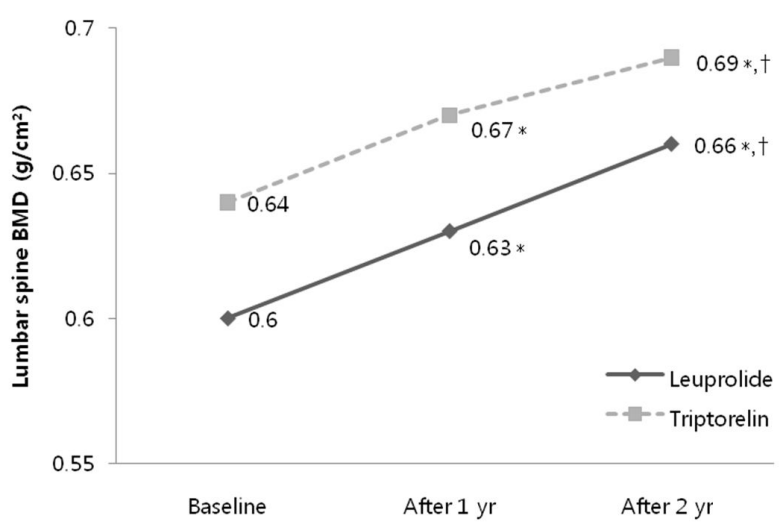

Fig. 1. The bone mineral density (BMD) of lumbar spines increased significantly in group A (leuprolide) from $0.60 \pm 0.06$ to 0.66 $\pm 0.06\left(\mathrm{~g} / \mathrm{cm}^{2}\right)$ and group B (triptorelin) from $0.64 \pm 0.05$ to 0.69 $\pm 0.04\left(\mathrm{~g} / \mathrm{cm}^{2}\right)$ during 2 years of treatment with $\mathrm{GnRH}$ analog ${ }^{*} P<0.05$ compared with baseline, ${ }^{\dagger} P<0.05$ compared with year 1.

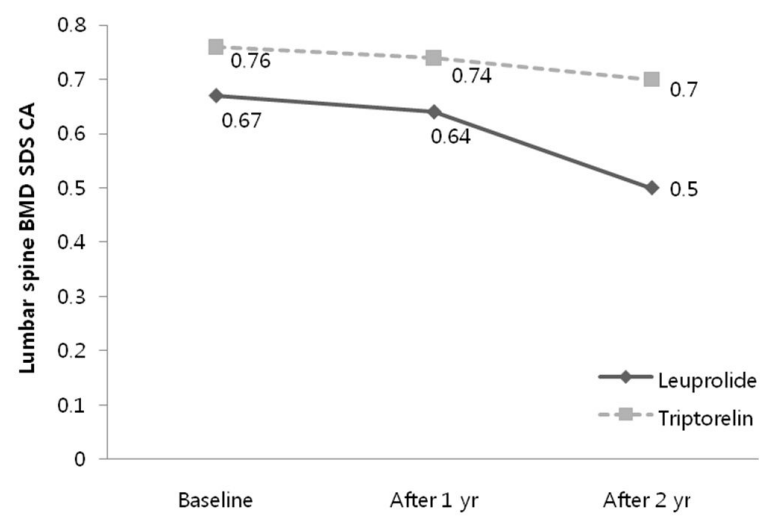

Fig. 2. The lumbar spine bone mineral density standard deviation score for chronological age (lumbar spine BMD SDS CA) showed no significant change in group A (leuprolide) from $0.67 \pm 0.94$ to $0.50 \pm 0.64\left(\mathrm{~g} / \mathrm{cm}^{2}\right)$ and group B (triptorelin) from $0.76 \pm 0.69$ to $0.70 \pm 0.55\left(\mathrm{~g} / \mathrm{cm}^{2}\right)$ during 2 years of treatment.

not change significantly.

\section{Discussion}

In our study we could see that lumbar spine BMD was not impaired in girls treated with GnRHa for CPP. Both GnRHa leuprolide-acetate and triptorelin showed comparable effects on lumbar spine BMD during and after treatment for 2 years.

GnRHa, for the treatment of CPP, are nowadays most commonly used in form of the depot products leuprolide-acetate and triptorelin ${ }^{13)}$. Their effect aims to decrease growth velocity to the appropriate levels for skeletal age and reverse the

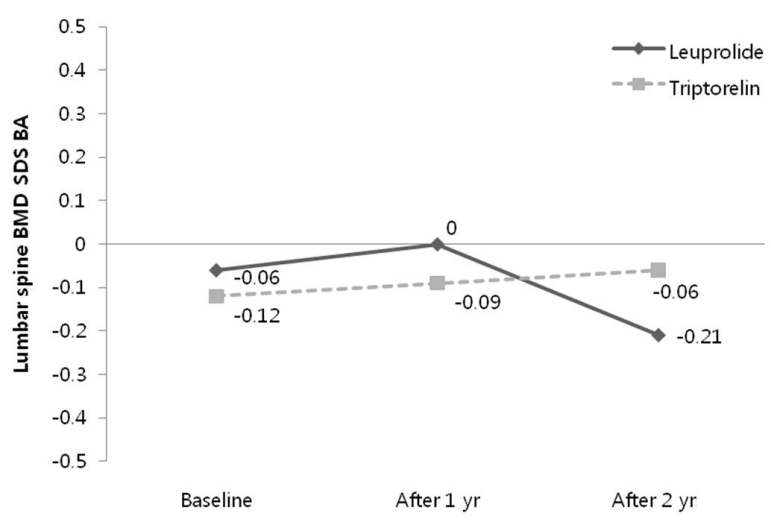

Fig. 3. The lumbar spine bone mineral density standard deviation score for bone age (lumbar spine BMD SDS BA) showed no significant change in group $A$ (leuprolide) from $-0.06 \pm 0.79$ to $-0.21 \pm 0.70\left(\mathrm{~g} / \mathrm{cm}^{2}\right)$ and group B (triptorelin) from $-0.12 \pm 0.62$ to $-0.06 \pm 0.29\left(\mathrm{~g} / \mathrm{cm}^{2}\right)$ during 2 years of treatment.

tendency to short stature in adulthood ${ }^{33}$. Such effects we could see in our study by a slowing down of inappropriate progression of BA maturation during GnRHa therapy, reflected in a change of BA/CA ratio from initial $1.18 \pm 0.19$ to 1.06 \pm 0.06 after 2 years of treatment. PAH also increased from initial $155.4 \pm 5.2 \mathrm{~cm}$ to $161.3 \pm 5.0 \mathrm{~cm}$ after 2 years of treatment.

Since GnRHa suppress the hypothalamus-pituitary-ovary axis, leading to a menopause-like phenomena, concerns about effects on fertility after ceasing treatment are given. Normal ovarian function after discontinuation of GnRHa treatment was shown in former studies ${ }^{4)}$. Another adverse effect of treatment to be considered is accelerated bone loss due to a decline in estrogen concentrations, as found in menopausal women and after surgical oophorectomy ${ }^{7)}$. The effects on BMD in children with CPP are still controversial. While one study by Yanovski et al. ${ }^{14)}$ showed a significant decrease in lumbar BMD several years after GnRHa treatment, others reported recovery of BMD values several years after withdrawal of treatment ${ }^{15)}$, or no change of BMD values during and after treatment ${ }^{16)}$. One goal of our study was to show the effect of GnRHa treatment on lumbar spine BMD values. While former studies compared the differences in effect of short-acting and depot agonists ${ }^{13)}$, we aimed to show possible differences in the effect of GnRHa leuprolide-acetate and triptorelin.

Lumbar spine BMD values of the whole group, as well as of each group A (leuprolide-acetate) and B (triptorelin) sepa- 
rately showed an increment, corresponding with an increment in bone mineralization during puberty ${ }^{7)}$. At baseline, in both groups, lumbar spine BMD values for CA were slightly elevated. Lumbar spine BMD SDS showed some decrement during 2 years of treatment, and were still in the positive range after therapy. Such changes were without statistical significance. Also, lumbar spine BMD SDS for BA in both groups showed similar findings, and changes were without statistical significance. One recent study conducted with 121 Korean girls, treated with depot leuprolide, showed comparable findings ${ }^{17)}$. Former studies with either one of the two GnRHa, leuprolide-acetate or triptorelin ${ }^{4,5)}$, showed comparable results about the effect on BMD, but other studies showing the effect of the two medications in comparison were not found.

One limitation to our study was the fact that there were no appropriate data as reference values for normal BMD results in Korean girls. Although a few papers were published about the normal values in BMD of Korean girls ${ }^{18,19)}$, the limited number of study subjects for each age group made it difficult to use as reference data, therefore we used the normal lumbar spine BMD values of the DEXA manufacturer as reference values ${ }^{12)}$, which seemed to be sufficient. Since this study only showed a short observation in treatment for about 2 years, the objects could not be observed until they reached their final heights. Further follow up until the study subjects reach their final heights might be necessary.

In conclusion, for the treatment with leuprolide-acetate and triptorelin, both GnRHa showed a comparable effect on lumbar spine BMD values during and after treatment. Longterm follow up of the subjects is needed to determine their lumbar spine BMD and final height results after discontinuance of GnRHa treatment.

\section{한 글 요 약}

\section{진성 성조숙증 여아에서 성선자극 호르몬 방출호르몬 자극제가 골밀도에 미치는 영향}

\author{
고려대학교 의과대학 소아청소년과 \\ 바우어 지그프리드 · 남효경·이영준 · 박상희 · 이기형
}

목 적 : 성조숙증이 있는 소아에서 성선자극호르몬 방출호 르몬 효능약제(gonadotropin releasing hormone analog,
$\mathrm{GnRHa})$ 치료 중 골밀도에 미치는 영향을 알아보고자 하였고, 특히 leuprolide-acetate과 triptorelin이 골밀도에 미치는 영향 을 비교 분석하였다.

방 법 : 총 61명의 성조숙증 여아를 대상으로 dual energy x-ray absorptiometry를 사용하여 치료 시작 전과 치료 1년 후 (61명) 및 치료 2년 후(24명)에 요추 골밀도를 측정하였다. 전 체 환아와, leuprolide-acetate 치료받은 아집단 $\mathrm{A}(40$ 명)와 triptorelin을 치료받은 아집단 $\mathrm{B}(21$ 명)의 골밀도 표준편차점 수를 각집단의 골연령과 역연령에 대하여 비교하였다.

결 과 : 치료를 받은 전체 환아에서 의미있는 골밀도 증가 를 보였다 $(P<0.05)$. 치료 전후에 역연령과 골연령으로 비교 한 골밀도 표준편차는 의미있는 변화가 없었다. 치료군 $\mathrm{A}$ 와 $\mathrm{B}$ 에서 치료중 골밀도 표준편차점수는 역연령이나 골연령 기 준으로 의미있는 차이를 보이지 않았다.

결 론: $\mathrm{GnRHa}$ 를 사용하는 성조숙증 여아에서 역연령이 나 골연령에 따른 골밀도의 저하는 관찰되지 않았다. 또한 leuprolide-acetate과 triptorelin의 비교에서도 골밀도에 대해 유의한 차이를 보이지 않았다

\section{References}

1) Mericq V, Lammoglia JJ, Unanue $N$, Villaroel $C$, Hernández MI, Avila A, et al. Comparison of three doses of leuprolide acetate in the treatment of central precocious puberty: preliminary results. Clin Endocrinol (Oxf) 2009;71:686-90.

2) Cutler GB Jr. The role of estrogen in bone growth and maturation during childhood and adolescence. J Steroid Biochem Mol Biol 1997;61:141-4.

3) Conn PM, Crowley WF Jr. Gonadotropin-releasing hormone and its analogs. Annu Rev Med 1994;45:391-405.

4) Magiakou MA, Manousaki D, Papadaki M, Hadjidakis D, Levidou G, Vakaki M, et al. The efficacy and safety of gonadotropin-releasing hormone analog treatment in childhood and adolescence: a single center, long-term follow-up study. J Clin Endocrinol Metab 2010;95:109-17.

5) Pasquino AM, Pucarelli I, Accardo F, Demiraj V, Segni M, Di Nardo R. Long-term observation of 87 girls with idiopathic central precocious puberty treated with gonadotropin-releasing hormone analogs: impact on adult height, body mass index, bone mineral content, and reproductive function. J Clin Endocrinol Metab 2008;93:190-5.

6) Antoniazzi F, Bertoldo F, Zamboni G, Valentini R, Sirpresi S, Cavallo L, et al. Bone mineral metabolism in girls with precocious puberty during gonadotrophin-releasing hormone agonist treatment. Eur J Endocrinol 1995;133:412-7.

7) Saggese G, Bertelloni S, Baroncelli GI, Battini R, Franchi G. Reduction of bone density: an effect of gonadotropin releasing hormone analogue treatment in central precocious 
puberty. Eur J Pediatr 1993;152:717-20.

8) van der Sluis IM, Boot AM, Krenning EP, Drop SL, de Muinck Keizer-Schrama SM. Longitudinal follow-up of bone density and body composition in children with precocious or early puberty before, during and after cessation of $\mathrm{GnRH}$ agonist therapy. J Clin Endocrinol Metab 2002;87:506-12.

9) Boot AM, De Muinck Keizer-Schrama S, Pols HA, Krenning EP, Drop SL. Bone mineral density and body composition before and during treatment with gonadotropin-releasing hormone agonist in children with central precocious and early puberty. J Clin Endocrinol Metab 1998;83:370-3.

10) Greulich WW, Pyle SI. Radiographic atlas of skeletal deve lopment of the hand and wrist. 2nd ed. Palo Alto, CA: Stanford University Press; 1959.

11) Bayley N, Pinneau SR. Tables for predicting adult height from skeletal age: revised for use with the Greulich-Pyle hand standards. J Pediatr 1952;40:423-41.

12) Kalkwarf HJ, Zemel BS, Gilsanz V, Lappe JM, Horlick M, Oberfield $\mathrm{S}$, et al. The bone mineral density in childhood study: bone mineral content and density according to age, sex, and race. J Clin Endocrinol Metab 2007;92:2087-99.

13) Tuvemo $T$. Treatment of central precocious puberty. Expert Opin Investig Drugs 2006;15:495-505.

14) Yanovski JA, Rose SR, Municchi G, Pescovitz OH, Hill SC, Cassorla FG, et al. Treatment with a luteinizing hormonereleasing hormone agonist in adolescents with short stature.
N Engl J Med 2003;348:908-17.

15) Kapteijns-van Kordelaar S, Noordam K, Otten B, van den Bergh J. Quantitative calcaneal ultrasound parameters and bone mineral density at final height in girls treated with depot gonadotropin-releasing hormone agonist for central precocious puberty or idiopathic short stature. Eur J Pediatr 2003;162:776-80.

16) Antoniazzi F, Zamboni G, Bertoldo F, Lauriola S, Mengarda F, Pietrobelli A, et al. Bone mass at final height in precocious puberty after gonadotropin-releasing hormone agonist with and without calcium supplementation. J Clin Endocrinol Metab 2003;88:1096-101.

17) Ko JH, Lee HS, Lim JS, Kim SM, Hwang JS. Changes in bone mineral density and body composition in children with central precocious puberty and early puberty before and after one year of treatment with GnRH agonist. Horm Res Paediatr 2011;75:174-9.

18) Oh YJ, La KS, Rhie YJ, Lee KH, Park SH, Choung JT, et al. Bone mineral density and correlation factors in normal children and adolescence. J Korean Soc Pediatr Endocrinol 2009; 14:38-44.

19) Lee SH, Desai SS, Shetty G, Song HR, Lee SH, Hur CY, et al. Bone mineral density of proximal femur and spine in Korean children between 2 and 18 years of age. J Bone Miner Metab 2007;25:423-30. 